\title{
Chalcophile element systematics in continental arc magmas as observed in the Central Andes
}

\author{
KANG CHEN $^{1,}{ }^{*}$, Ming TANG ${ }^{2}$, SUZANNE M. KAY ${ }^{3}$, \\ ZAICONG WANG ${ }^{1}$, ZHAOCHU HU ${ }^{1}$, YongShENG LiU ${ }^{1}$ \\ ${ }^{1}$ State Key Laboratory of Geological Processes and Mineral \\ Resources, China University of Geosciences, Wuhan 430074, \\ China; ${ }^{*}$ kangchen@cug.edu.cn \\ ${ }^{2}$ School of Earth and Space Sciences, Peking University, \\ Beijing 100871, China; \\ ${ }^{3}$ Department of Earth \& Atmospheric Sciences, Cornell \\ University, Ithaca, NY 14853, USA;
}

Two series of volcanic rocks from the Central Andes are investigated for chalcophile elements $(\mathrm{Cu}, \mathrm{Zn}, \mathrm{Ga}, \mathrm{Ge}, \mathrm{Mo}$, $\mathrm{Ag}, \mathrm{Cd}, \mathrm{In}, \mathrm{Sn}, \mathrm{Te}, \mathrm{W}, \mathrm{Tl}, \mathrm{Pb}$ and $\mathrm{Bi}$ ) in order to quantify their behavior during magma differentiation in a continental arc setting. One series of the samples show slowly decreasing $\mathrm{FeOT}$ (total $\mathrm{Fe}$ ) and increasing $\mathrm{Sr} / \mathrm{Y}, \mathrm{Sm} / \mathrm{Yb}$ and $\mathrm{Dy} / \mathrm{Yb}$ along with decreasing $\mathrm{MgO}$, indicative of equilibration with a plagioclase-free, garnet-bearing residue (named "garnet-effect series" hereafter). Samples in the other series reveal rapidly diminishing $\mathrm{FeOT}, \mathrm{TiO}_{2}$ and $\mathrm{V}$, and gently decreasing $\mathrm{Dy} / \mathrm{Yb}$ as differentiation proceeds, suggesting the fractionation of amphibole and magnetite (named "amphibole-effect series" hereafter). Sulfide saturation occurred for the whole compositional ranges in both series as evidenced by the decreasing $\mathrm{Cu}$ concentrations and reducing $\mathrm{Cu} / \mathrm{Ag}$ along with differentiation. The decreasing $\mathrm{Cu} / \mathrm{Ag}$ also suggest the fractionated sulfide phases are crystalline, not liquid sulfides. Additionally, the lower $\mathrm{Cu} / \mathrm{Ag}$ in the most primitive samples from both series than in MORB imply that sulfides have saturated at very early stages during the differentiation of their parental magmas. We believe that sulfide saturation in the garnet-effect series was caused by the high pressure and the depleted FeOT, both of which have negative effects on sulfur concentration at sulfide saturation (Smythe et al., 2017). By contrast, sulfide fractionation in the amphibole series was triggered probably by magnetite fractionation, which scavenged the FeOT and reduced redox condition in the magma (Jenner et al., 2010; Jugo et al., 2010). Sn, W, Tl, Pb and $\mathrm{Bi}$, which are nominally chalcophile elements, show incompatible behavior, whereas $\mathrm{Cd}$ and $\mathrm{In}$ are compatible, during the differentiation of both magma series.

\section{References}

Jenner et al., 2010. J. Petrol. 51 (12) 2445-2464. Jugo et al., 2010. Geochim. Cosmochim. Acta 74 (20) 5926-5938. Smythe et al., 2017. Am. Mineral. 102 (4) 795-803. 